\title{
The Effect of Prolonged Irrigation on Soil-amelioration State of the Aley River Steppe in Altai Krai
}

\section{Roman Gornostal}

Altai State Agrarian University, Barnaul, Russia

\section{Abstract}

On the basis of many years of research conducted at the Aley River irrigation system and generalization of literary materials, the impact of irrigation on soil fertility, composition and properties of chernozemic, meadow chernozemic and chernozemic meadow soils, their water and salt regime, and crop productivity has been established. A comprehensive assessment of the long-term impact of irrigation on the change in the hydrophysical and chemical properties of soils and the ecological and reclamation state of the irrigated area is given. The influence of long-term irrigation on the nature and direction of the dynamics of groundwater and salt levels in soils is revealed. The

Corresponding Author: Roman Gornostal col4e@mail.ru

Received: 25 October 2019 Accepted: 15 November 2019 Published: 25 November 2019 Publishing services provided by Knowledge E

(c) Roman Gornostal. This article is distributed under the terms of the Creative Commons

Attribution License, which permits unrestricted use and redistribution provided that the original author and source are credited.

Selection and Peer-review under the responsibility of the AgroSMART 2019 Conference Committee.

\section{G OPEN ACCESS} water and salt balance of soils has been compiled, depending on the characteristics and duration of irrigation. It is proved that in conditions of insufficient drainage of the territory, non-compliance with scientifically grounded irrigation regimes, rational irrigation techniques, violation of agricultural technology and crop rotation during long-term irrigation leads to the deterioration of some properties of soils, their salinization and alkalination. Regularities and changes in soil-amelioration conditions during prolonged irrigation of land have been established.

Keywords: soil, salinization, irrigation, irrigation methods.

\section{Introduction}

Altai Krai is the largest agricultural region in Western Siberia with more than 10 million hectares of agricultural land, out of which arable land is 7 million hectares.

Due to harsh climatic features, soil productivity is inferior to that of similar soil and bioclimatic zones of the European part of Russia.

One of the most important reasons for the low crop yield is the lack of natural water availabilty in the soil, therefore, the degree of agricultural production intensity in the region is small.

A powerful way to increase crop yields under these conditions is irrigation. Natural resources of the region make it possible to provide irrigation for more than 1 million 
hectares of land. The main fund of agricultural land is situated in the steppe regions of the Altai Krai, more than $60 \%$ of arable land is located there.

The development of irrigated agriculture is of great importance for farms located in the Aley River steppe, there is a significant fluctuation of precipitation there with often repeated droughts and, as a consequence, unstable yields. All these factors led to the construction of one of the largest irrigation systems (the Aley River irrigation system) in Western Siberia in 1914.

During the period of intensive exploitation from the 1930s to the 1990s, when irrigating, they were often guided not by moisture requirements of crops, but only by economic opportunities with a constant increase in irrigated area, which by 1986 had reached its maximum of 25 thousand hectares.

In carrying out agricultural activities, large violations were noted. The current planning was practically not carried out. There was no proper care of the irrigation network and its structures. A large volume of irrigation water was discharged [16].

Efficiency coefficient of the system was 0.22 , and water utilization coefficient was 0.26--0.40. All these data indicate extreme trouble in the water sector of the system.

Due to the violation of agricultural technology, improper operation of the system and non-compliance with the irrigation regime of crops, the threat of widespread salinization of irrigated lands and a deterioration in the general soil fertility has occured.

From the 1990s to the 2000s, a critical decline was observed in the country's agroindustrial complex, including irrigated agriculture. During this period, the total irrigation area of the Aley River irrigation system decreased to $10 \%$ and amounted to 2500 ha. The infrastructure of the abandoned area was no longer used in agriculture.

As a result, the country's food security was on the verge of destruction and Russia was forced to purchase large quantities of imported agricultural products [2].

Since the 2000s, the state has launched programs to stimulate the production of its own agricultural products, including the intensive development of the reclamation industry.

The Aley River irrigation system was included in the list of objects, embraced by the program "Development of Land Reclamation of the Russian Federation 2014--2020" [7].

The chosen research object has been in operation for more than 100 years, which could not but effect the development of certain environmental problems, associated with the degradation and depletion of natural resources. 
The main objective of the study is to identify the effect of prolonged irrigation on the changes in soil properties in order to preserve and reproduce their fertility, increase crop yields. The following tasks are set:

- to assess the change in soil properties of the Aley River irrigation system during prolonged irrigation;

- to study the basic hydrophysical and agrochemical properties of irrigated soils under the influence of prolonged irrigation and the type of agricultural use;

- to study the water and salt regime of irrigated soils and evaluate its changes due to long-term irrigation;

- to give recommendations on restoration of soils based the conducted research

\section{Description of the Method}

The experimental scheme and research methods used in the study

As it is known, anthropogenic factors significantly affect the soil-forming processes, resulting is new properties of soils, which leads to a change in their level of fertility. Irrigation radically changes the water regime of soils, the direction of the soil-forming processes and soil fertility. At the same time, a new agro-irrigation layer is created on the surface, and the soil is transformed into a completely different type. In the area of irrigated agriculture and with prolonged irrigation, negative processes often occur and, as a rule, the ecological and reclamation state of soils worsens gleying and secondary salinization are noted. Therefore, in our studies it was envisaged to identify changes occurring in soil fertility depending on the characteristics of soil conditions and the irrigation period.

The studies were conducted in 2014--2018 on the lands of the Aley River irrigation system at the following farms: LLC "Aleksandrovka" (the village Novoaleksandrovka), peasant farm "Sleptsov" (the settlement Zelenaia Dubrava), SPK collective farm "Sibir" (the village Veselyi lar), the former land of state farm "Tekhnikum", Open Society State Farm "Nikolskii", (the settlement Bezrukavka) LLC "Novorossiiskoe", (the settlement Novorossiiskii). At the farms, stationary irrigated plots were selected and dynamic observation platforms of 1 hectare $(100 \times 100 \mathrm{~m})$ in size were allocated. Observation wells to study the regime of groundwater were located next to the dynamic platforms. On these plots, soil profiles and wells were laid to determine the properties of soils and their fertility. Dynamic sites were replications, located on the same type of soil with approximately the same occurrence depth of the groundwater. At some dynamic sites, 
research was carried out in two to three replications so that in each variant there were at least four repetitions.

Field experiement was started in 2014 and was carried out over the past five years (from 2014 to 2018). During this period, perennial herbs were cultivated in all variants of the experiment. The experiment was organized as follows (Table 1).

Field and laboratory studies were carried out using generally accepted methods. Soil samples for laboratory analyses were taken in the period of soil ripeness. Samples were taken in layers. Physical and hydrophysical properties of soils were determined following methods, described in the works of S.V. Astapova (1958), N.A. Kachinskii (1945, 1965, 1970) and A.F. Vadiunina, Z.A. Korchagina (1986).

Granulometric composition was determined by the method of N.A. Kachinskii, structural and aggregate composition (dry sieving) according to the method of N.I. Savinova, the water stability of soil aggregates (wet sieving) using the device of I.M. Baksheev.

The density of soil structure was determined by the cutting ring method without disturbing the soil structure, and the density of the solid phase of the soil was determined by the density bottle method. The firmness of the soil was determined with the help of N.F. Golubev's density meter by the profile method. The total porosity was determined by calculation, and the aeration porosity was determined by the difference between the volumes of the total soil porosity and the water porosity.

The minimal moisture capacity ( $M M C$ ) was determined in the field by the poured pads method with the subsequent determination of humidity by thermostatic and gravimetric method. The water permeability of the soil was determined by the method of S. I. Dolgov. (1966). Productive humidity was determined by the difference between the actual humidity and wilting moisture. The latter was determined by calculation on the maximum hygroscopicity (MG) data:

$$
W M=M G 1,5
$$

The maximal hygroscopic moisture was determined by the method of A.V. Nikolaev.

The rate of absorption and filtration was calculated by the formula:

$$
K=W / F t(\mathrm{~cm} / \mathrm{min})
$$

where $\mathrm{W}$ is the volume of water supplied, $\mathrm{cm}^{3}$;

$F$ is the base area of the inner cylinder, $\mathrm{cm}$;

$t$ is the time of maintaining the water layer, min.

The filtration rate was determined after establishing a constant flow rate of flowing water. 
Chemical analysis of the soil was carried out by the generally accepted methods, described in the work by E.V. Arinushkina (1970). Soil acidity (pH of the aqueous extract) was determined by the potentiometric method using a $\mathrm{pH}$ meter, the content of humus by I.V. Tiurin's method, absorption capacity of the exchange base according to the method of K.K. Gedroits. The content of total nitrogen was determined by the method of Kjeldahl and that of easily hydrolyzed nitrogen on the method of I.V. Tiurin. The content of total phosphorus and potassium was determined by the method of Lorentz and Machigin, mobile forms of phosphorus and potassium on the method of Chirikov in non-carbonate soils and by the method of Machigin in carbonate ones. Alcalination of the soil was determined by the presence of metabolic sodium in the soil absorption complex (PPC). The biological activity of the soil was determined twice during the growing season the activity of cellulose-destroying microorganisms by the application method described by E.N. Mishustin and I.S. Vostrov (1971), nitrification ability of the soil by the method of Kravnov (A.V. Petersburgskii, 1968), the intensity of "respiration" of soil -- by the method of V.I. Shtatnov (1952). Soil moisture was determined by thermostatic and gravimetric method at the beginning and the end of vegetation of perennial grasses, as well as before each watering. In the test area, soil moisture was determined once or twice a month.

Sampling for determining the salt regime of soils was carried out twice a year in spring and autumn. Watersoluble cations ( $\mathrm{K}, \mathrm{Na}, \mathrm{Ca}, \mathrm{Mg}$ ) and anions ( $\mathrm{SO} 4, \mathrm{Cl}, \mathrm{CO} 3$ ) were determined by making water soil extract in a ratio of $1: 5$. Determination of the content of potassium and sodium was carried out by flame photometry and that of calcium and magnesium by the titrimetric method with Trilon B, of sulfates by the gravimetric method (or titration), of chlorides by titration with silver nitrate, and the dry residue was determined by the gravimetric method. The occurrence depth of groundwater was measured by using observation wells.

Irrigation water and groundwater samples were obtained by taking samples from water sources and wells of the regime network. In the analysis of irrigation water and groundwater we used the manual by lu. lu. Lurie (1984). Chemical analysis was carried out according to the following indicators: $\mathrm{pH}$ by potentiometry, carbonates by the titrometric method, chlorides by the titrometric method with silver nitrate; sulfates by gravimetric method; calcium and magnesium by volumetric complexometric method; sodium, potassium by flame photometry on the "Flamo" device; the dry residue by gravimetric method. 
Irrigation was carried out with a decrease in soil moisture to $70 \% \mathrm{HB}$. The actual irrigation rate was determined by rain gauge reservoirs. Water consumption of plants was calculated by the water balance method.

Agricultural technology for soybean cultivation in all areas was the one generally accepted for this zone. Record keeping of soybean yield was carried out on the experimental plots manually by gravimetric method for all variants of the experiment in four repetitions. The test plot area was $10 \mathrm{~m}^{2}$.

Processing of the crop data was carried out by the dispersion method (B.A. Dospekhov, 1979).

TABLE 1: Plots investigated.

\begin{tabular}{|c|c|c|c|}
\hline Variant no. & Soil type & $\begin{array}{c}\text { Location of the stationary } \\
\text { plot }\end{array}$ & Dynamic site \\
\hline \multicolumn{4}{|c|}{ I. Old irrigated zone, more than 55 years } \\
\hline \multirow[t]{2}{*}{1} & Meadow chernozemic & LLC “Aleksandrovka" & 4,6 \\
\hline & & peasant farm "Sleptsov" & 3 \\
\hline \multirow[t]{3}{*}{2} & $\begin{array}{c}\text { Chernozemic meadow } \\
\text { meameadowЧерноземно- } \\
\text { лугоВая }\end{array}$ & LLC “Aleksandrovka" & 5 \\
\hline & & peasant farm "Sleptsov" & 33 \\
\hline & & LLC "Novorossiyskoe" & 36 \\
\hline \multicolumn{4}{|c|}{ II. Newly irrigated zone, more than 35 years } \\
\hline \multirow[t]{2}{*}{3} & Meadow chernozemic & $\begin{array}{l}\text { The former land of state } \\
\text { farm "Tekhnikum" }\end{array}$ & 24 \\
\hline & & $\begin{array}{l}\text { Open Society State Farm } \\
\text { "Nikolskii" }\end{array}$ & 8 \\
\hline 4 & Chernozemic meadow & $\begin{array}{l}\text { Open Society State Farm } \\
\text { "Nikolskii" }\end{array}$ & $48(7)$ \\
\hline \multicolumn{4}{|c|}{ III. Newly irrigated zone, more than $\mathbf{2 5}$ years } \\
\hline 5 & $\begin{array}{c}\text { Southern chernozem } \\
\text { chernozemЧернозем } \\
\text { южный }\end{array}$ & $\begin{array}{l}\text { Open Society State Farm } \\
\text { "Nikolskii" }\end{array}$ & 27,28 \\
\hline \multirow[t]{2}{*}{6} & Meadow chernozemic & $\begin{array}{l}\text { The former land of state } \\
\text { farm "Tekhnikum" }\end{array}$ & 34 \\
\hline & & LLC "Novorossiyskoe" & 32 \\
\hline 7 & Southern chernozem & $\begin{array}{l}\text { Open Society State Farm } \\
\text { "Nikolskii" }\end{array}$ & Dry-farming land \\
\hline
\end{tabular}




\section{Results Obtained in the Course of Research}

We have studied hydrophysical and agrochemical properties of soils in accordance with research variants. Table 2 shows that, over a long period of irrigation, soil compaction, a decrease in total porosity and a slight increase in the minimal moisture capacity has occurred. As for agrochemical indicators, the content of humus, total nitrogen, and absorption capacity has decreased. The content of mobile forms of phosphorus and potassium in the arable layer of the soil, depending on the duration of irrigation, have not change much, their content was even higher compared with the dry-farming land (Variant 7).

It should be noted that the soil acidity index during long-term irrigation from 8.2 to 7.2 has decreased compared to the dry-farming land, and the initially slightly alkaline soil has approached the neutral reaction $(\mathrm{pH} 7.1$ of chernozemic meadow soils of the old irrigation zone).

In general, in the beginning of research, southern and meadow chernozemic soils had the most favorable hydrophysical and agrochemical properties. In chernozemic meadow soils a greater compaction, a decrease in porosity, humus and total nitrogen contents and absorption capacity were noted.

As it is known, one of the important physical quantities of soil, characterizing the conditions for plant growth and development is aeration porosity. The study of aeration during the growing season of plants in the course of agricultural crops cultivation makes it possible to apply agricultural methods more correctly, depending on the duration of irrigation and the crop grown [1].

The structure of the arable layer is favorable and is characterized by the total porosity of $55--65 \%$ and the porosity of stable aeration of $15--30 \%$.

The optimal porosity for loamy and clay soils according to N.A. Kachinskii is 50--65 $\%$, and the aeration porosity, according to S.I. Dolgov and S.A. Modina (1969) is at least $13 \%$. Our data (Table 3) showed that the total porosity and aeration porosity tended to decrease with an increase in the duration of irrigation. On the southern non-irrigated chernozem (variant 7), these indicators were favorable, while in the old-irrigated zone, especially on chernozem-meadow soils (variant 2), they fell below the optimal values [10].

On average, over the years of research (2014--2018) under dry-farming conditions (variant 7), the total porosity was 50.4, 47.7 and $49.1 \%$, respectively, in the soil layers of $0--30 \mathrm{~cm}, 03--30 \mathrm{~cm}$ and $0--60 \mathrm{~cm}$, and the stable aeration porosity was 21.1, 16.5 and $18.8 \%$, respectively. Compared to the dry-farming land, the southern chernozem, 
TABLE 2: Main hydrophysical and agrochemical properties of soils, in a layer of $0--30 \mathrm{~cm}$ at the beginning of research (2014).

\begin{tabular}{|c|c|c|c|c|c|c|c|}
\hline \multirow[t]{2}{*}{ Indicators } & \multicolumn{7}{|c|}{ Variants } \\
\hline & 1 & 2 & 3 & 4 & 5 & 6 & 7 \\
\hline $\begin{array}{l}\text { Density of soil structure } \\
\mathrm{g} / \mathrm{cm}\end{array}$ & 1,40 & 1,42 & 1,36 & $1,3.8$ & 1,29 & 1,33 & 1,2 \\
\hline $\begin{array}{l}\text { Density of solid phase, } \\
\mathrm{g} / \mathrm{cm}^{3}\end{array}$ & 2,64 & 2,65 & 2,61 & 2,62 & 2,59 & 2,60 & 2,5 \\
\hline General density, \% & 47,0 & 46,4 & 47,9 & 47,3 & 50,2 & 48,8 & 51,6 \\
\hline $\begin{array}{l}\text { Minimal moisture capacity, } \\
\text { (MMC), \% of mass }\end{array}$ & 24,7 & 25,4 & 23,5 & 24,1 & 22,4 & 23,2 & 22,2 \\
\hline Humus, \% & 3,31 & 3,32 & 3,40 & 3,36 & 3,49 & 3,41 & 3,5 \\
\hline Total nitrogen, \% & 0,14 & 0,12 & 0,14 & 0,13 & 0,17 & 0,16 & 0,1 \\
\hline $\begin{array}{l}\text { Mobile forms of } \\
\text { phosphorus, } \mathrm{mg} / 100 \mathrm{~g}\end{array}$ & 15,07 & 15,16 & 14,93 & 15,01 & 14,78 & 14,85 & 14,1 \\
\hline $\begin{array}{l}\text { Exchangeable potassium, } \\
\mathrm{mg} / 100 \mathrm{~g} \mathrm{r} \text {. }\end{array}$ & 46,6 & 45,0 & 43,3 & 45,8 & 41,7 & 42,5 & 32,6 \\
\hline $\mathrm{PH} \mathrm{H}_{2} \mathrm{O}$ & 7,2 & 7,1 & 7,4 & 7,3 & 7,6 & 7,5 & 8,2 \\
\hline $\begin{array}{l}\text { Absorption capacity, } \\
\text { mg-equivalent per } 100 \mathrm{~g} \text { of } \\
\text { soil }\end{array}$ & 24,1 & 22,14 & 27,25 & 25,8 & 29,5 & 27,98 & 29,3 \\
\hline
\end{tabular}

irrigated for 30--35 years (variant 5), demonstrated the decrease in total porosity by 1.3--1.4 \%, and in stable aeration --- by 1.7--1.9\%.

The structure of the arable layer $(0--30 \mathrm{~cm})$ remained favorable, despite the fact that the total porosity during the irrigation period decreased by $6 \%$. On meadow chernozemic soils with approximately the same irrigation period (variant 6), the total porosity decreased on average to $48.5 \%$, and the aeration porosity to $18.1 \%$. In this variant the aeration porosity remained optimal, and the total porosity was slightly lower than the optimal value [14].

With the duration of irrigation of $40--45$ years (variants 3--4), the aeration porosity was within the optimal range, and the total porosity of the upper soil layer of $0--30 \mathrm{~cm}$ was decreasing over the years of research on average to $46.9-47.5 \%$, with the optimal lower rise of $50 \%$. Over the years of irrigation, there was a decrease in the total porosity in these variants by an average of $8 \%$, and the stable aeration porosity was 16.4--16.5 $\%$, staying favorable.

However, in the subsurface layer the aeration porosity decreased to 13.1--13.7 \%, and the total porosity to $43.6--44.5 \%$ on average. The same tendency was also observed there: the total porosity was below the optimum and the aeration porosity dropped to the 
lower permissible limit. Moreover, on meadow chernozemic soils the porosity remained more favorable compared to chernozemic meadow soils of the same irrigation period.

The porosity of the soil compared to the initial data has significantly changed in the old irrigated zone, where the duration of irrigation is more than 50 years. Thus, on meadow chernozemic soils, the total porosity of the arable $(0--30 \mathrm{~cm})$ and subsurface $(30--60 \mathrm{~cm})$ layers over the years of research was on average 46.2 and $43.6 \%$, respectively, and the aeration porosity was 14.6 and $13 \%$. These data indicate the unfavorable structure of the arable layer, although the porosity of stable aeration for loamy soils remained close to the lower permissible limit. It should be noted that the total porosity of the arable layer $(0--30 \mathrm{~cm})$ over a long period of irrigation decreased by $14 \%$ and amounted to $53.7 \%$, while the optimal porosity for loamy soils was $50 \%$.

On black-meadow soils with a period of prolonged irrigation of more than 50 years (variant 2), the porosity of the soil was even less favorable. Here, in the upper soil layer of 0--30 cm, the total porosity was below the optimum level by $9.0 \%$ (45.7\% on average), and the aeration porosity approached the lower permissible margin and averaged 14.4 $\%$. Over the long irrigation period the total porosity of the upper soil layer $(0-30 \mathrm{~cm})$ decreased from 53.1 to $45.3 \%$ (2018) or by $14.7 \%$. In the subsurface layer (30--60 cm), the total porosity amounted to $43.1 \%$ on average for $2014--2018$, which is significantly below the optimal level. Compared to the original porosity, it decreased by $8.9 \%$. The aeration porosity in this case was unfavorable on average over the years of research and averaged $12.7 \%$.

TABLE 3: Effect of prolonged irrigation on the change in soil porosity.

\begin{tabular}{|c|c|c|c|c|c|c|c|c|}
\hline $\begin{array}{l}\text { Variant } \\
\text { no. }\end{array}$ & $\begin{array}{l}\text { Layer of } \\
\text { soil. cm }\end{array}$ & $\begin{array}{c}\text { Initial } \\
\text { data }\end{array}$ & 2014 & 2015 & 2016 & 2017 & 2018 & $\begin{array}{l}\text { Average for } \\
2014--2018\end{array}$ \\
\hline 1 & 2 & 3 & 4 & 5 & 6 & 7 & 8 & 9 \\
\hline \multicolumn{9}{|c|}{ Total porosity. \% } \\
\hline 1 & $\begin{array}{c}0--30 \\
30--60 \\
0--60\end{array}$ & $\begin{array}{l}53.7 \\
48.3 \\
51.0\end{array}$ & $\begin{array}{l}47.0 \\
43.6 \\
45.3\end{array}$ & $\begin{array}{l}46.2 \\
44.4 \\
45.3\end{array}$ & $\begin{array}{l}45.8 \\
42.9 \\
44.4\end{array}$ & $\begin{array}{l}46.6 \\
34.2 \\
44.9\end{array}$ & $\begin{array}{l}46.2 \\
43.2 \\
44.7\end{array}$ & $\begin{array}{l}46.2 \\
43.6 \\
44.9\end{array}$ \\
\hline 2 & $\begin{array}{c}0--30 \\
30--60 \\
0--60\end{array}$ & $\begin{array}{l}53.1 \\
47.3 \\
50.2\end{array}$ & $\begin{array}{l}46.4 \\
43.1 \\
44.8\end{array}$ & $\begin{array}{l}45.7 \\
43.4 \\
44.6\end{array}$ & $\begin{array}{l}46.0 \\
42.7 \\
44.4\end{array}$ & $\begin{array}{l}45.3 \\
43.1 \\
44.2\end{array}$ & $\begin{array}{l}45.3 \\
43.1 \\
44.2\end{array}$ & $\begin{array}{l}45.7 \\
43.1 \\
44.4\end{array}$ \\
\hline 3 & $\begin{array}{c}0--30 \\
30--60 \\
0--60\end{array}$ & $\begin{array}{l}51.6 \\
46.3 \\
49.0\end{array}$ & $\begin{array}{l}47.9 \\
44.9 \\
46.4\end{array}$ & $\begin{array}{l}47.1 \\
45.2 \\
46.2\end{array}$ & $\begin{array}{l}48.3 \\
44.5 \\
46.4\end{array}$ & $\begin{array}{l}46.7 \\
43.7 \\
45.2\end{array}$ & $\begin{array}{l}47.1 \\
44.5 \\
45.8\end{array}$ & $\begin{array}{l}47.5 \\
44.5 \\
46.0\end{array}$ \\
\hline 4 & $\begin{array}{c}0--30 \\
30--60 \\
0--60\end{array}$ & $\begin{array}{l}51.0 \\
46.9 \\
49.0\end{array}$ & $\begin{array}{l}47.3 \\
43.9 \\
45.6\end{array}$ & $\begin{array}{l}47.3 \\
43.9 \\
45.6\end{array}$ & $\begin{array}{l}46.6 \\
43.2 \\
44.9\end{array}$ & $\begin{array}{l}46.9 \\
43.6 \\
45.3\end{array}$ & $\begin{array}{l}46.6 \\
43.6 \\
45.1\end{array}$ & $\begin{array}{l}46.9 \\
43.6 \\
45.3\end{array}$ \\
\hline
\end{tabular}




\begin{tabular}{|c|c|c|c|c|c|c|c|c|}
\hline $\begin{array}{l}\text { Variant } \\
\text { no. }\end{array}$ & $\begin{array}{l}\text { Layer of } \\
\text { soil. cm }\end{array}$ & $\begin{array}{l}\text { Initial } \\
\text { data }\end{array}$ & 2014 & 2015 & 2016 & 2017 & 2018 & $\begin{array}{l}\text { Average for } \\
2014--2018\end{array}$ \\
\hline 1 & 2 & 3 & 4 & 5 & 6 & 7 & 8 & 9 \\
\hline 5 & $\begin{array}{c}0--30 \\
30--60 \\
0--60\end{array}$ & $\begin{array}{l}52.3 \\
47.3 \\
49.8\end{array}$ & $\begin{array}{l}50.2 \\
46.8 \\
48.5\end{array}$ & $\begin{array}{l}49.8 \\
45.6 \\
47.7\end{array}$ & $\begin{array}{l}48.6 \\
46.8 \\
47.7\end{array}$ & $\begin{array}{l}49.0 \\
46.8 \\
47.9\end{array}$ & $\begin{array}{l}48.3 \\
46.4 \\
47.7\end{array}$ & $\begin{array}{l}49.0 \\
46.4 \\
47.7\end{array}$ \\
\hline 6 & $\begin{array}{c}0--30 \\
30--60 \\
0--60\end{array}$ & $\begin{array}{l}51.6 \\
46.5 \\
49.1\end{array}$ & $\begin{array}{l}48.8 \\
46.2 \\
47.5\end{array}$ & $\begin{array}{l}48.1 \\
46.6 \\
47.4\end{array}$ & $\begin{array}{l}48.8 \\
45.8 \\
47.3\end{array}$ & $\begin{array}{l}48.1 \\
45.5 \\
46.8\end{array}$ & $\begin{array}{l}47.7 \\
45.5 \\
46.6\end{array}$ & $\begin{array}{l}48.5 \\
45.8 \\
47.2\end{array}$ \\
\hline 7 & $\begin{array}{c}0--30 \\
30--60 \\
0--60\end{array}$ & -- -- -- & $\begin{array}{c}52.3 \\
47.7 \\
50\end{array}$ & $\begin{array}{l}50.8 \\
48.1 \\
49.5\end{array}$ & $\begin{array}{l}51.6 \\
46.9 \\
49.3\end{array}$ & $\begin{array}{l}51.2 \\
47.7 \\
49.5\end{array}$ & $\begin{array}{l}50.4 \\
47.3 \\
48.9\end{array}$ & $\begin{array}{l}50.4 \\
47.7 \\
49.1\end{array}$ \\
\hline \multicolumn{9}{|c|}{ Aeration porosity. \% } \\
\hline 1 & $\begin{array}{c}0--30 \\
30--60 \\
0--60\end{array}$ & & $\begin{array}{l}14.9 \\
13.0 \\
14.0\end{array}$ & $\begin{array}{l}14.7 \\
13.7 \\
14.2\end{array}$ & $\begin{array}{l}14.2 \\
12.6 \\
13.4\end{array}$ & $\begin{array}{l}14.8 \\
12.9 \\
13.9\end{array}$ & $\begin{array}{l}14.7 \\
12.9 \\
13.8\end{array}$ & $\begin{array}{l}14.6 \\
13.0 \\
13.9\end{array}$ \\
\hline 2 & $\begin{array}{c}0--30 \\
30--60 \\
0--60\end{array}$ & & $\begin{array}{l}15.1 \\
12.7 \\
13.9\end{array}$ & $\begin{array}{l}14.3 \\
12.9 \\
13.6\end{array}$ & $\begin{array}{l}14.5 \\
12.6 \\
13.6\end{array}$ & $\begin{array}{l}14.0 \\
12.7 \\
13.4\end{array}$ & $\begin{array}{l}14.1 \\
12.7 \\
13.4\end{array}$ & $\begin{array}{l}14.4 \\
12.7 \\
13.6\end{array}$ \\
\hline \multirow[t]{3}{*}{3} & $0--30$ & & 17.4 & 16.5 & 17.7 & 16.0 & 15.0 & 16.5 \\
\hline & $30--60$ & & 13.9 & 14.3 & 13.5 & 13.2 & 13.4 & 13.7 \\
\hline & $0--60$ & & 15.7 & 15.4 & 15.6 & 14.6 & 14.2 & 15.1 \\
\hline \multirow[t]{3}{*}{4} & $0--30$ & & 17.2 & 16.1 & 17.3 & 15.9 & 15.4 & 16.4 \\
\hline & $30--60$ & & 13.2 & 13.2 & 13.0 & 13.0 & 12.9 & 13.1 \\
\hline & $0--60$ & & 15.2 & 14.7 & 15.2 & 14.5 & 14.2 & 14.8 \\
\hline \multirow[t]{3}{*}{5} & $0--30$ & & 20.3 & 19.7 & 19.5 & 18.6 & 18.2 & 19.3 \\
\hline & $30--60$ & & 15.2 & 14.1 & 14.8 & 14.9 & 15.1 & 14.8 \\
\hline & $0--60$ & & 17.8 & 16.9 & 17.2 & 16.8 & 16.7 & 17.1 \\
\hline \multirow[t]{3}{*}{6} & $0--30$ & & 18.5 & 17.9 & 18.6 & 18.0 & 17.4 & 18.1 \\
\hline & $30--60$ & & 14.9 & 15.1 & 14.6 & 14.2 & 14.2 & 14.6 \\
\hline & $0--60$ & & 16.7 & 16.5 & 16.6 & 16.1 & 15.8 & 16.4 \\
\hline \multirow[t]{3}{*}{7} & $0--30$ & & 21.5 & 20.9 & 21.1 & 21.3 & 20.6 & 21.1 \\
\hline & $30--60$ & & 16.5 & 16.8 & 16.2 & 16.6 & 16.4 & 16.5 \\
\hline & $0--60$ & & 19.0 & 18.9 & 18.7 & 19.0 & 18.5 & 18.8 \\
\hline
\end{tabular}

In general, porosity is characteristically decreasing with an increase in the irrigation period, as well as in the process of transformation into meadow. In the years of research the differences in porosity were insignificant, although there was a tendency to its decrease with short irrigation periods.

Thus, the structure of the arable layer is the most favorable in the non-irrigated variant and with short periods of irrigation (not more than 20--30 years) In the old-irrigated zone 
(more than 50 years) the structure of the arable and especially subsurface layer was less favorable and periodic deep reclamation treatments are required to improve it. It should be noted that, according to our calculations, the tendency of deterioration of the arable layer structure, which was initially favorable, was also noted for irrigation periods of up to 20 years. Compared to the dry-farming land, with the prolonged irrigation the soil structure density has increased from 1.26 to $1.44 \mathrm{~g} / \mathrm{cm}$, firmness from 14.2 to 25.1 $\mathrm{kg} / \mathrm{cm}$, the total porosity and aeration have decreased from 50.4 to $45.7 \%$ and from 21.1 to $14.4 \%$ respectively.

With the duration of irrigation up to 20 years, the soils possessed favorable structural characteristics and water stability. The content of agronomically valuable aggregates in the arable layer (0--30) exceeded $76 \%$, and that of water-stable ones was more than $0.25 \mathrm{~mm} 56 \%$. With an increase in the irrigation period up to 50 years or more, a deterioration in the structural-aggregate composition of the soil was noted. The content of agronomically valuable aggregates decreased to $60 \%$, and that of water-stable ones to $25 \%$.

The moisture capacity and water permeability of the soils had rather high indices, characteristic of the medium-loamy southern chernozem. As the duration of irrigation increases, the lowest moisture capacity in the soil layer of 0--30 cm tended to increase on average from $20.4 \%$ (on the dry-farming land) to $24.5 \%$ (on chernozemic meadow soils with irrigation of more than 50 years), and the maximum productive moisture reserve from 50 to $54 \mathrm{~mm}$. The water permeability of soils in 6 hours decreased from $1096 \mathrm{~mm}$ (3.05 mm/min) to $581 \mathrm{~mm}(1.61 \mathrm{~mm} / \mathrm{min})$ or 1.9 times.

The content of humus (Table 4$)$ in the arable soil layer $(0--30 \mathrm{~cm}$ ) decreased with an increase in irrigation duration from $3.35 \%$ (the dry-farming land) to $2.65 \%$ (chernozemic meadow soils with irrigation period of more than 50 years). On the newly irrigated southern chernozem and meadow chernozemic soils under irrigation of up to 20--30 years, the humus content was $2.98--3.27 \%$, and, when irrigated for more than 50 years, the humus content on chernozemic meadow soils decreased to $2.65 \%$, but the humus horizon was more stretched.

The groundwater level at the Aley River irrigation system under conditions of weak natural drainage rose from 5--7 to $2.0--2.1 \mathrm{~m}$ as a result of the long-term irrigation. Groundwater lies most deeply from the surface (more than $5 \mathrm{~m}$ ) on the southern newly irrigated chernozem, and is close to the surface $(2.0--2.8 \mathrm{~m})$ on chernozemic meadow soils with the irrigation period of more than 50 years. 
With an increase in the duration of irrigation, there is a gradual increase in groundwater mineralization, from fresh to weakly mineralized water, and in drainless depressions to medium and highly mineralized water.

The salt regime of soils with an increase in the duration of irrigation was noticeably deteriorating. In the southern chernozem, non-irrigated and irrigated for 10--17 years, the content of toxic salts in 1 meter layer did not exceed $0.04-0.06 \%$ and the soils remained uninhabited. In meadow chernozemic soils with 20--30 years of irrigation duration, the amount of toxic salts increased on average to $0.15--0.24 \%$, and with the duration of more than 50 years up to $0.33 \%$, and soils accordingly became weakly- and medium salinized [1]. The chernozemic meadow soils were characterized by an average degree of salinization, but were characterized by the highest content of toxic salts ( 0.39 and $0.49 \%$, respectively, with irrigation period of more than 20 and 50 years).

In the process of research, we selected areas with different irrigation durations for soybean sowing and yield determination. The highest yields of soybean were obtained on the southern chernozem irrigated for 10--17 years (on average $2.5 \mathrm{t} / \mathrm{ha}$ ) and were 2 times higher than on the dry-farming land ( $1.3 \mathrm{t} / \mathrm{ha})$. On meadow chernozemic soils with the irrigation duration of 10--17 years, 20--30 years and more than 50 years, the productivity decreased in comparison with the irrigated chernozem by $0.3 \mathrm{t} / \mathrm{ha}, 0.6$ and $0.8 \mathrm{t} / \mathrm{ha}$, or by 12,24 and $32 \%$ respectively. Soybean productivity on chernozemic meadow soils was the lowest and, compared with the southern irrigated chernozem, decreased by 1.0 and $1.2 \mathrm{t} / \mathrm{ha}$.

\section{Conclusions and Suggestions}

At present, the Aley River irrigation system is undergoing the process of reconstruction and modernization of equipment, but all this can be in vain without the cardinal shift in attention to the soil reclamation component of agricultural land.

First of all, it is necessary to improve the quality of irrigated lands using agrotechnical tools, namely, it is necessary to lighten the fertile soil layer which, over a long period of irrigation, has significantly compacted and does not allow all nutrients to penetrate.

Second, to restore soil fertility at the Aley River irrigation system during prolonged irrigation (more than 11-17 years), it is recommended to use an integrated irrigated farming system for individual irrigated plots, taking into account the duration of irrigation. A mandatory element of this system is the application of organic and mineral fertilizers, following ecologically safe standards and the introduction of grain-grass crop rotation, providing a positive balance of humus. When practicing overhead irrigation, it 
TABLE 4: Content of humus in the variants of the experiment, \%.

\begin{tabular}{|c|c|c|c|c|c|c|c|c|}
\hline $\begin{array}{l}\text { Variant } \\
\text { no. }\end{array}$ & $\begin{array}{l}\text { Layer of } \\
\text { soil, cm }\end{array}$ & $\begin{array}{c}\text { Initial } \\
\text { data } \\
\text { before } \\
\text { irrigation }\end{array}$ & 2014 & 2015 & 2016 & 2017 & 2018 & $\begin{array}{l}\text { Average for } \\
\text { 2014--2018 }\end{array}$ \\
\hline 1 & $\begin{array}{c}0--30 \\
30--60 \\
0--60\end{array}$ & $\begin{array}{l}3.47 \\
1.95 \\
2.71\end{array}$ & $\begin{array}{l}3.31 \\
2.48 \\
2.9\end{array}$ & $\begin{array}{l}2.8 \\
2.6 \\
2.7\end{array}$ & $\begin{array}{l}2.59 \\
1.95 \\
2.27\end{array}$ & $\begin{array}{l}2.67 \\
2.1 \\
2.39\end{array}$ & $\begin{array}{l}2.68 \\
2.4 \\
2.54\end{array}$ & $\begin{array}{l}2.81 \\
2.31 \\
2.56\end{array}$ \\
\hline 2 & $\begin{array}{c}0--30 \\
30--60 \\
0--60\end{array}$ & $\begin{array}{l}3.76 \\
2.22 \\
2.99\end{array}$ & $\begin{array}{l}3.24 \\
2.01 \\
2.63\end{array}$ & $\begin{array}{l}2.57 \\
2.5 \\
2.5\end{array}$ & $\begin{array}{l}2.47 \\
2.28 \\
2.38\end{array}$ & $\begin{array}{l}2.39 \\
2.0 \\
2.2\end{array}$ & $\begin{array}{l}2.6 \\
2.2 \\
2.4\end{array}$ & $\begin{array}{l}2.65 \\
2.20 \\
2.42\end{array}$ \\
\hline \multirow[t]{3}{*}{3} & $0--30$ & 3.74 & 3.4 & 2.92 & 3.03 & 3.23 & 3.78 & 3.27 \\
\hline & 30--60 & 2.90 & 2.3 & 2.3 & 2.15 & 2.17 & 1.9 & 2.16 \\
\hline & $0--60$ & 3.32 & 2.85 & 2.61 & 2.59 & 2.7 & 3.0 & 2.72 \\
\hline \multirow[t]{3}{*}{4} & $0--30$ & 3.31 & 3.36 & 2.8 & 2.59 & 2.7 & 1.99 & 2.69 \\
\hline & $30--60$ & 2.44 & 2.01 & 1.75 & 1.47 & 1.9 & 1.87 & 1.80 \\
\hline & $0--60$ & 2.88 & 2.69 & 2.27 & 2.03 & 2.3 & 1.93 & 2.24 \\
\hline \multirow[t]{3}{*}{5} & $0--30$ & 3.85 & 3.49 & 3.0 & 3.1 & 3.0 & 2.33 & 2.98 \\
\hline & $30--60$ & 2.15 & 2.91 & 1.9 & 2.2 & 2.7 & 1.8 & 2.30 \\
\hline & $0--60$ & 3.0 & 3.2 & 2.45 & 2.65 & 2.85 & 2.07 & 2.64 \\
\hline \multirow[t]{3}{*}{6} & $0--30$ & 3.68 & 3.41 & 3.36 & 3.0 & 3.1 & 2.61 & 3.09 \\
\hline & $30--60$ & 2.12 & 2.17 & 2.64 & 2.12 & 2.4 & 1.8 & 2.23 \\
\hline & $0--60$ & 2.9 & 2.79 & 3 & 2.56 & 2.75 & 2.21 & 2.66 \\
\hline \multirow[t]{3}{*}{7} & 0--30 & -- & 3.58 & 3.47 & 3.51 & 3.30 & 3.78 & 3.53 \\
\hline & $30--60$ & -- & 2.35 & 1.97 & 2.44 & 2.27 & 2.19 & 2.23 \\
\hline & $0--60$ & -- & 2.97 & 2.72 & 2.97 & 2.79 & 2.98 & 2.89 \\
\hline
\end{tabular}

is necessary to observe the optimal irrigation regime with norms at which groundwater does not rise and secondary salinization and alcalination of soil are not observed. In the system of agrotechnical measures it is necessary to provide for lesser use of heavy equipment, and to implement the technology of cultivating crops in accordance with the zonal recommendations for irrigation. Thirdly, in order to maintain the groundwater occurrence depth below the critical level, it is necessary to provide a closed drainage on poorly drained lands, and to reduce soil compaction during prolonged irrigation, it is advisable to conduct deep loosening once per crop rotation.

Fourthly, in order to reduce the average irrigation norm and the overall ecological load per 1 hectare of irrigated area, it is necessary to provide for cultivation of crops with different levels (intensity) of water consumption. 


\section{Discussion}

The analysis of the data obtained during research showed that in the process of prolonged irrigation lasting more than 50 years, dramatic changes in the soil-reclamation state of irrigated lands occur, as demonstrated by indicators of the salt regime of soils, their humus content, density of soil structure, etc.

As a result, there is a decrease in crop yields, e.g. soybean in our studies. The results of the harvest show that the highest rates were obtained in areas with shorter irrigation duration, namely less than 25 years, since all indicators characterizing soil reclamation state were within the average acceptable range.

Based on the materials obtained, a system of measures has been developed to improve the soil reclamation and agroecological state of the Aley River irrigation system. Recommendations are made for production aimed at scientifically grounded use of irrigated lands. Suggestions are given for the preservation and reproduction of the fertility of irrigated soils and crop yields increase.

\section{References}

[1] Aidarov, I.P. (1985). Regulation of water-salt and nutrient regimes of irrigated lands. Moscow: Agropromizdat, 275 p.

[2] Blagoveshchenskii Yu.N., Samsonova, V.P. (2016). Bayesian Approach in Agrochemical Surveys. Moscow University Soil Science Bulletin, vol. 71, no. 4-5, pp. 147--150. ISSN 0147-6874.

[3] Burlakova, L.M. (1986). Problems of changing chernozems during irrigation. Development of land reclamation in the Altai Krai. Barnaul, p. 21--24.

[4] Denisov, V.I. (2019). Acceleration of the Development of Agriculture in the Russian Economy by Increasing the Efficiency of the State Support of Rural Commodity Producers. Studies on Russian Economic Development, vol. 30, no. 1, pp. 66--74. ISSN 1075-7007.

[5] Efimov, A.E., Sitdikova, Yu.R., Dobrokhotov, A.V., Kozyreva, L.V. (2018). Monitoring Evapotranspiration in an Agricultural Field and Determination of Irrigation Rates and Dates by Automated Mobile Field Agrometeorological Complex. Water Resources, vol. 45, no. 1, pp. 133--137. ISSN 0097-8078.

[6] On Land Reclamation. Federal Law of 10 January 1996 no. 4-Ф3.

[7] Federal target program "Development of land reclamation of agricultural lands of Russia for 2014--2020". 
[8] Golovanov, A.I. et al. (2015). Land reclamation. Moscow: Lan, 816 p.

[9] Ilinskaia, I.N. Ignatiev, V.M. (2013). Calculation of environmentally safe water demand for irrigation of crops. Bulletin of the Russian Academy of Agricultural Sciences, no. 5, pp. 26--28.

[10] Kachinskii, N.A. (1965). Soil physics. Part 1. Moscow: Higher school, 324 p.

[11] Kostiakov, A.N. (1933). Fundamentals of land reclamation, 3rd ed. Textbook. Moscow; Leningrad: Gos. Izd-vo kolkhoz. i sovkhoz. Lit., 887 p.

[12] Olgarenko G.V. (2015). A technique for the operational diagnosis of degradation of reclaimed soils to justify complex measures for the conservation and expanded reproduction of fertility. Scientific edition FSBI VNII "Raduga". Kolomna: IP Vorobyov O.M., 52 p.

[13] Reclamation Problems. Ministry of Agriculture of the Russian Federation. Retrieved from: http://www.mcx.ru/.

[14] Sorokin, A.S., Kust, G.S. (2018). Diagnostics of Compaction of Arable Soils in the Transvolga Region in Saratov Oblast. Moscow University Soil Science Bulletin, vol. 73, no. 1, pp. 1--5. ISSN 0147-6874.

[15] State program of the Altai Krai "Development of land reclamation of the Altai Krai agricultural lands".

[16] Vorobeva, R.P. (2003). The history of the development of land reclamation in Altai. Barnaul: Azbuka, 244 p. 